Article

\title{
Boundary Crossers: The Transformation of Civil Society Elites in Indonesia's Post-Authoritarian Era
}

\author{
Haryanto
}

Department of Politics and Government, Faculty of Social and Political Science, Universitas Gadjah Mada, 55281 Sleman, Indonesia; E-Mail: haryantojpp@ugm.ac.id

Submitted: 11 March 2020 | Accepted: 10 June 2020 | Published: 4 September 2020

\begin{abstract}
This article discusses the strategies used by the leaders of civil society organisations (CSOs) to cross the boundary between the field of civil society and the field of the state. Moreover, it examines the implications of this boundary crossing for post-authoritarian politics in Indonesia. In doing so, it tries to answer two questions: First, what are the strategies used by CSO leaders in boundary crossing? Second, what are the political implications of this boundary crossing for Indonesia's post-authoritarian politics? Using Bourdieu's field theory as its conceptual framework and drawing on qualitative interviews with CSO leaders, this article scrutinises the mobility of CSO leaders in different sectors: agrarian, anti-corruption, law, and human rights. It identifies two main strategies used in boundary crossing: direct and indirect strategies. Such strategies tend to be individual rather than organisational. Neither strategy is exclusive; CSO leaders do not limit themselves to particular strategies but may combine them and use them simultaneously. Another finding is that, when crossing to the state field, CSO leaders may increase or reduce their capital, or even lose it. Furthermore, boundary crossing has several significant implications for post-authoritarian politics in Indonesia: it generates sectoral policies; it creates political linkages; and finally, it leads CSO leaders to exert political control within the state field.
\end{abstract}

\section{Keywords}

boundary crosser; boundary strategies; Bourdieu; civil society elites; civil society organisations; Indonesia; political implications

\section{Issue}

This article is part of the issue "Civil Society Elites" edited by Håkan Johansson (Lund University, Sweden) and Anders Uhlin (Lund University, Sweden).

(C) 2020 by the author; licensee Cogitatio (Lisbon, Portugal). This article is licensed under a Creative Commons Attribution 4.0 International License (CC BY).

\section{Introduction}

Interactions between state, economic, and civil society actors are common in countries around the world (Lewis, 2008; Moore, Sobieraj, Whitt, Mayorova, \& Beaulieu, 2002). These interactions occur dynamically, with diverse forms that are influenced by the political structure of the state. Authoritarian regimes tend to have antagonistic relationships with pro-democracy civil society elements (Uhlin, 1997), while democratic governments generally have more open and plural relationships with civil society elements.

The political changes that have fundamentally transformed Indonesia since 1998 have also informed state- civil society relations. There has been an awareness of the need to "use democratic institutions to ensure popular control over public affairs" (Savirani \& Törnquist, 2016; Stokke \& Törnquist, 2013). At the same time, however, the continued predominance of the predatory elite in Indonesia's democracy has resulted in "civil society actors seeking to influence the government not only from the margins of civil society but from within the power centres of political institutions" (Mietzner, 2013). This clearly shows that civil society actors in postauthoritarian use political endeavours to enter the state and play a political role within it.

To understand this phenomenon, this article examines the strategies through which civil society elites cross 
the boundary between the 'civil society field' and the 'state field' in post-authoritarian Indonesia. Civil society elites may be identified based on their dominant position in the civil society field or in broader social relations, which they gain by accumulating social, economic, cultural, and symbolic capital. Following the positional approach (Hoffmann-Lange, 2017), formal leadership positions may indicate elite status. However, this study is not concerned with the identification of individual civil society leaders as belonging to an elite group; rather, it focuses on the power dynamics of their boundarycrossing activities.

This theme is interesting to explore, not only because it expands the discussion of civil society-state relations, but also because it offers a detailed understanding of the civil society organisations (CSOs) leaders' boundary-crossing activities. Civil society is predominantly perceived as an autonomous field, and CSOs are often seen as opposed to the state. Nielsen (2012), for example, showed that "politics is perceived as dirty, unprincipled, dishonest, and corrupt, and thus incapable of accommodating activists' moral struggle." Such a perception is not entirely correct; as Alagappa notes, "the relations between civil society and the state are dynamic, occurring over a broad spectrum, rather than entirely confrontational" (Alagappa, 2004). Brinkerhoff and Brinkerhoff (2011) have also shown that civil societystate partnerships may be established during the development process; James Ryker, in his categorisation, elaborates that state-civil-society relations can take place in many forms such as autonomous, facilitation, collaboration/cooperation, co-optation, and containment (Ryker, 1995, pp. 208-211).

In Indonesia, some scholars have explored the dynamics of civil society-state relations. Lay (2017a, 2017b) has mapped CSOs political linkages within the policymaking process; Aspinall (2014) has examined their relations within the context of political transformation; and Mundayat, Narendra, and Irawanto (2009) have found that their relations depend heavily on the strength of civil society and the effectiveness of governance. In general, Philip Eldridge emphasises that relations between CSOs and the government in Indonesia are generally pragmatic, characterised by both co-operation and conflict (Eldridge, 1996, p. 30). From these studies, it can be seen that the relations between the state and civil society are complex.

Nonetheless, few studies of civil society-state relations in Indonesia have examined how actors cross the boundary from the civil society field to the state field. This practice, known as 'boundary crossing' (Lewis, 2008), is relatively widespread around the globe. As political systems transform from authoritarian to democratic, civil society actors are driven to cross boundaries (Abers \& Tatagiba, 2015; Lewis, 2008; Mietzner, 2013; Perdana, 2015). Studies that have considered this phenomenon are limited to efforts to explain CSO actors' motivations for boundary crossing (Mietzner, 2013) and the charac- teristics of the practice itself (Lewis, 2008). The current article seeks to fill this gap by elaborating upon the strategies used by the CSO leader when crossing boundaries.

In describing boundary-crossing practices, the article answers two main questions: First, what are the strategies used by CSO leaders in boundary crossing? Second, what are the political implications of boundary crossing for post-authoritarian politics in Indonesia? I find that, in post-authoritarian Indonesia, two main strategies are used by civil society elites in boundary crossing: first, 'direct strategies,' wherein civil society leaders become politically engaged as candidates in election processes; second, 'indirect strategies,' wherein civil society elites follow a zig-zag route into the state. In this second strategy, civil society leaders do not follow a singular route into the state. They may move from subfield to subfield, strengthen their relationships with other CSOs, or become involved in political processes as volunteers. Boundary crossing has several implications for post-authoritarian politics: It generates sectoral policies, creates political linkages, and leads CSO leaders to exert political control within the state field.

This article's examination of leaders' boundarycrossing strategies focuses on those involved in the agrarian, anti-corruption, law, and human rights sectors at the national and local level. These sectors were chosen based on a review of the literature and discussions with experts. These processes also become a point of departure to identify in each sector how civil society leaders cross over to the state field. Data were collected through in-depth interviews with CSO leaders, political party actors, and local officials, as well as two focus group discussions. Complementary data were collected by reviewing related documents. In data collection, multiple aspects were considered, including the personal background of CSO leaders, career, experience in civil society field, motivation to enter the state field, aspects that facilitated the process, evaluation of boundarycrossing experience, etc. The research was conducted in Yogyakarta, Makassar, Kupang, and Jakarta between October 2018 and July 2019 as part of a collaboration between Lund University, Sweden, and Universitas Gadjah Mada, Indonesia. The research was conducted at both the national and regional level, as both are important to consider in the decentralised political environment of post-authoritarian Indonesia.

In describing the boundary-crossing strategies of civil society elites, the article presents both a general overview and illustrative cases. After assessing extant studies of boundary crossing as a general practice, this article offers a specific elaboration on the Indonesian case. It presents the history and political context of border crossing, two main strategies, and the implications of the practice. The article also offers a brief comparative analysis in its last section, showing the similarities and differences between boundary-crossing practices in Indonesia and other countries. 


\section{Boundary Crossing: An Overview}

Civil society is often understood as distinct from the state, and this implies that a boundary exists between them (Rosenblum \& Lesch, 2011). In essence, this distinction is rooted in particular assumptions, norms, ideologies, and epistemologies about civil society and the state. The liberal tradition, for example, has viewed civil society as independent from the state; this view is rooted in liberal regulative principles that position civil society as an independent, self-regulating, and autonomous associational space. In such a view, the state only serves to promote a pluralist associational life.

However, this boundary is not impermeable; civil society and the state are dynamically related. In this context, Chandhoke (2001) argues that "civil society cannot be defined as entirely separate from the state, as these fields are intertwined and mutually related." Alagappa (2004), examining civil society in Asia, finds that civil society-State relations occur on a broad spectrum and are incredibly diverse.

In this dynamic state-civil society setting, boundarycrossing practice has a political significance to elaborate. Mietzner (2013), in a study of a CSO activist, identifies several types of boundary crossers: (1) those who deliberately use CSOs as stepping stones to enter the state field, (2) those who remain with their CSOs when political opportunities are lacking, but immediately enter the state field when it is possible, and (3) those who cross for ideological reasons and seek to improve the political system from within. Mietzner notes that CSO actors may also be active in an intersectional space, not joining political parties or becoming part of the bureaucracy, but still advising government ministries and legislative bodies. Actors in such intersectional spaces may be identified as employing indirect strategies, not contesting elections but still using their capital to shape policy as expert staff or advisors. In such situations, activists touch upon the state field, even as they remain active within civil society.

Within post-authoritarian states, boundary crossing can also be seen as a consequence of the permeability of the state-civil society boundary. While authoritarian states reject criticism and repress civil society, postauthoritarian ones are open and accommodative. In such situations, the state is not situated solely as an object of monitoring and criticism, but also as a strategic partner that may facilitate the realisation of goals and enactment of change (Abers \& Tatagiba, 2015). Seizing this momentum, CSO leaders may decide to take part in the formal power structure rather than continue to struggle outside it (Abers \& Tatagiba, 2015).

The above-discussed studies contribute to a clear understanding of the structural setting of civil society-state relations as well as their dynamics. However, they have yet to reveal an important dimension of these relations: CSO leaders' ability to cross boundaries and enter the state field. As such, this article seeks to examine the practice of boundary crossing, with particular focus on its strategies.

\section{Field Theory and Boundary Crossing}

This article's exploration of leaders' crossing to the state field refers to Bourdieu $(1986,1989,1996)$, particularly his concepts of 'field,' 'capital,' and 'habitus.' Field refers to the gaming space within which power relations occur. In the field, agents mobilise or organise their available capital and utilise it strategically to access specific positions (Bourdieu, 1986, 1989, 1996; Swartz, 1997). This article uses the field to refer specifically to civil society (including the networks between civil society actors) and the state (including the networks between political actors). The state field refers to the political spaces in which social agents can make political decisions (such as policy); as such, the basic logic of the state field is its authoritative ability to make a political decision. In this article, the state field encompasses the legislative and executive branches. Conversely, the civil society field refers to the social space that is mobilised by the logics of association, self-organisation, advocacy, and social empowerment, which is ultimately distinguished from the state field by its lack of authoritative force to make policies and political decisions.

The concept of field cannot be separated from the concept of capital, as capital is the main resource that enables actors to act and compete within the field (Bourdieu, 1986). Bourdieu identifies four types of capital: social, economic, cultural, and symbolic. Following Bourdieu's concept, the capital used by CSO leaders to cross boundaries to the state field may be identified as networking (social capital), funding (economic capital), knowledge accumulation (cultural capital), and symbolic capital.

As a practice, boundary-crossing is not only determined by agents' ability to mobilise capital within the field but also by their habitus. As stated by Bourdieu, "practice is produced through the interaction of disposition (habitus) and position within the field, as determined by capital possession" (Bourdieu as cited in Maton, 2008, p. 50). Using this framework, it can be recognised that boundary-crossing practices reflect the habitus of CSO leaders and are made possible by their ability to mobilise capital.

Drawing from Bourdieu's field theory, this article analyses the strategies employed by CSO leaders to cross into the state field. Leaders' strategies are influenced by the habitus and the capital available to them, their ability to utilise it, and their environment-i.e., the dominant political system.

In this article, 'boundary crossing' is understood as CSOs leaders' movement from the civil society field to the state field. Such crossing may occur directly, through the contestation of legislative and executive elections, or indirectly, through zig-zagging from subfield to subfield (i.e., from human rights to anti-corruption) within the 
civil society field before entering the state field. Referring to the model offered by Lewis (2008), the former is a 'consecutive model' through which CSO elites directly cross boundaries by moving from civil society to the state, while the latter is an 'extensive model' wherein CSO elites do not fully cross boundaries, but only 'span' them, being simultaneously involved in civil society and state activities.

\section{Boundary Crossing in Indonesia}

\subsection{History and Political Context}

State-civil society relations in Indonesia have dynamic historical roots. In the early years of independence, considerable antagonism existed within the state field-the main field of power. This condition affected the dynamics of civil society. As Aspinall remarked, "civil society became a mechanism, not for generating civility and social capital, but rather for magnifying socio-political conflict and transmitting it to the very bases of society" (Aspinall, 2004, p. 62).

Political intrigue and bloodshed soon brought Indonesia into a dark period, one in which political space was strictly controlled and a logic of authoritarianism permeated every aspect of Indonesian society. This regime identified itself as the New Order and employed a range of depoliticisation strategies. First, it used an 'archepolitics' strategy in a communitarian attempt to define and organically structure homogeneous social space. President Soeharto was constructed as a father figure, as a source of order and harmony. Second, the regime used a 'para-politics' strategy, seeking to mitigate political conflict by way of formulating clear rules. This was reflected in the New Order's fusion of political parties, allowing only two parties and one functional group to exist. Third, it used an 'ultra-politics' strategy, using militarisation to promote depoliticisation (Duile \& Bens, 2017).

The authoritarian regime's consolidation of power had a direct effect on civil society actors' relationship with the state and their ability to enter the state field. In the early years of the New Order (1966-1974), several civil society activists were able to cross into the state. These activists, known collectively as the "Generation of '66," had been staunch opponents of the Sukarno government's authoritarian regime (Noor, 2010, p. 22; Uhlin, 1997, p. 102). However, as the New Order regime became increasingly authoritarian, civil society became subordinated. State-civil society relations became increasingly antagonistic in the 1980s and 1990s, and civil society leaders could no longer penetrate the state field.

Reformasi (Indonesia's political reform), which began in 1998, resulted in the opening of political spaces through democratisation. It created and multiplied democratic spaces in both the national and local arenas (Lay, 2017b), enabling CSO actors to become more heavily involved in politics. In the early years of Reformasi, several civil society leaders became key drivers of re- form; however, most civil society actors were floating, being vulnerable and lacking capacity to enter the state arena. They were what political scientists termed 'floating democrats' (Priyono, Prasetyo, \& Törnquist, 2003).

In the post-authoritarian era, which remains plagued by fundamental problems such as weak political representation and limited ability to penetrate the state, efforts have been made to repoliticise civil society actors through a process known as 'go politics.' Five major strategies have been employed: (1) forming pressure groups, (2) entering parliament, (3) utilising political parties, (4) establishing alternative political parties, and (5) entering government networks (Samadhi \& Törnquist, 2016, p. 116; Törnquist, 2009).

Entering parliament and participating in elections has been a favoured strategy for go politics in civil society, as noted by the Indonesian Institute of Sciences (Ichwanuddin, 2010) in its study of civil society actors' use of the 2009 national and local elections to enter the state. According to Mietzner (2013), 37 (7\%) of the legislators elected in 2009 had a background in activism. In 2013, the Power, Welfare, and Democracy Project recorded that such strategies had created linkages between CSO actors, political parties, and populist politicians (Törnquist \& Samadhi, 2016).

However, CSO actors have not only crossed into the political field through elections; they have also used indirect routes as a means for exerting political power. This involves a 'zig-zagging' process through which CSO leaders move from one subfield to another before entering the state field. This indirect strategy creates an extensive model of boundary crossing, meaning that CSO leaders not only fill new positions within the state field but also retain a certain position in the civil society field.

To obtain a specific understanding of the two strategies mentioned above, we must examine their use in boundary crossing in more detail.

\subsection{Direct and Indirect Strategies}

CSO leaders who enter the state field come from various subfields but share similar views of civil society's position in post-authoritarian Indonesia. To advance reform, they must involve themselves in the state. As stated by Teten Masduki, a CSO leader active in the anti-corruption subfield:

Good people should be pushed to enter government, to become directors general, to become regents, mayors, or even members of parliament. Civil society actors must enter the government so they can become champions, pioneers, and promote reform. That must be a priority. (Teten Masduki, interview, June 27, 2019)

A similar attitude was expressed by CSO leaders who were active in the agrarian subfield, who argued that agrarian reform is a political agenda that must be priori- 
tised by the state. For example, Usep Setiawan, a CSO leader active in this subfield, stated: "I would say that agrarian reform must be promoted by the state. The government, as the administrator of the state, must handle such reform" (Usep Setiawan, interview, June 27, 2019).

A similar view was expressed by Iwan Nurdin, another CSO leader, who stated: "Agrarian reform must necessarily involve political processes. We must recognise that agrarian reform is not a non-political issue. It has been political from the beginning" (Iwan Nurdin, interview, June 27, 2019).

These shared motives have driven the CSO leader to cross boundaries. They have sought to reach beyond civil society and have broader effects on society. If referring to Bourdieu, "the boundaries of a field can be recognised based on its influences" (Bourdieu \& Wacquant, 1992), then the practice of boundary crossing can be seen as an effort to expand their influence to another field.

As explained previously, two strategies are commonly used by civil society leaders for boundary crossing, reflecting the different channels and mechanisms used by civil society leaders. 'Direct strategies' are marked by a reliance on electoral mechanisms to enter the state field, while 'indirect strategies' - though more variedshare the common feature of zig-zagging from subfield to subfield.

\subsubsection{Direct Strategy}

One common strategy used by civil society leaders to cross over to the state field is the direct strategy, so named as civil society leaders rely on elections to cross boundaries. In the direct strategy, civil society leaders actively engage as candidates in electoral contestation.

Civil society leaders' use of direct strategies to enter the state field must be positioned within the context of post-authoritarian politics, particularly the transformation of the national, provincial, and district parliaments through the amendment of the 1945 Constitution. Under the New Order government, parliament merely served as a rubber stamp for the executive branch. However, since Reformasi, parliament has become a new space for national politics and policymaking (Lay, 2017b, p. 7); as such, political parties have taken a strategic role in policymaking and political processes. At the same time, the mechanisms through which parliament functions have changed and the political climate has become more open, allowing civil society actors to take a more active role in parliament (Lay, 2017b).

To obtain a detailed understanding of how civil society leaders use elections to enter the state, it is necessary to understand how their 'habitus' and 'capital,' as well as their ability to organise and mobilise capital, influence their ability to cross boundaries. Civil society leaders' habitus reflects the way they think and act, providing a basis for their boundary-crossing practices.

The habitus of civil society leaders is strongly linked to their experiences, as well as the knowledge that guides their practices. Two key habitus provide a foundation for civil society leaders' use of elections for boundary crossing: the empowerment experiences that inform their society-orientated practices, and the experiences that underpin their advocacy logics. Both provide a foundation for enabling civil society leaders to enter the state. As mentioned by Sofia de Haan, a civil society leader in Kupang (Yayasan Alfa Omega), East Nusa Tenggara:

I think that, if we stay outside of the system and not within it, it will be difficult for us. Even though we've already established a basis for empowerment. They (the people) can be involved in policymaking processes at the village level. However, they lack influence. As such, the decision to become a member of the local parliament was made to advocate their rights. (Sofia de Haan, interview, April 25, 2019)

A similar logic provided the foundation for the boundary crossing undertaken by Tomy Yulianto, a civil society leader from Bulukumba Regency. As he said:

I spent nine years in East Kalimantan, did my best to create change in society and improve the system. I spent too long away from home. All of my experiences, all of the knowledge I obtained over the course of my journey. I should use my competencies to help my hometown. That's what made me decide to enter parliament. (Tomy Yulianto, interview, April 20, 2019)

If advocacy and empowerment are the logics that underpin boundary-crossing practices, what enables civil society leaders to enter the state through elections (which require political parties)? As often noted, political parties in post-authoritarian Indonesia lack public trust, and as such, they are frequently criticised by civil society activists. It is thus difficult to imagine how the habitus of civil society leaders can be in-line with the habitus of political parties.

To understand this phenomenon, it is necessary to consider the logic used by political parties when recruiting civil society actors. A study of civil society actors conducted by the Indonesian Institute of Sciences (2010) found that they are not recruited through a 'transactional logic'; in other words, economic exchange is not the central logic through which candidates from civil society backgrounds are recruited. Rather, parties require a symbolic means of showing their concern for voters. Manor (2013) calls this 'post-clientelist' politics, that is, a politics made up of political connections in which politicians and parties opt to cooperate with well-reputed leaders and civil society organisations. There is thus no logical contradiction involved in boundary-crossing practices. As emphasised by Sofia de Haan:

The party's main consideration is quality. CSO actors know the roots of the problems, are capable of revealing needs. Now more CSO actors are involved in political parties, and many of them succeed. Several 
have become council members. Parties recognise that CSO actors have constituents and are involved in their communities. Furthermore, certain leadership qualities are recognised by parties. (Sofia de Haan, interview, April 25, 2019)

As with habitus, capital plays a central role in civil society leaders' choice of direct strategies. The knowledge and networks that they accumulate provide them with capital that they can utilise to penetrate the state. Cultural capital (i.e., knowledge) and social capital (i.e., networks amongst the grassroots) determine two things in boundary-crossing processes: first, these leaders' positions within political parties and their electability in the election process.

Sofia's experience provides an interesting example. An activist and leader with the Alfa Omega Foundation, an NGO actively promoting economic empowerment and rights fulfilment for farmers, fishermen, and the poor, Sofia had significant bargaining power when dealing with political parties. Owing to her background as an activist, as well as her recognition as an activist, she could not only empower others but also influence politics. Sofia's capabilities were buttressed by the knowledge that she had accumulated through organisational, training, and educational activities at the national and international levels. At the same time, she enjoyed significant social capital. The daughter of a priest, she had been active in church activities throughout East Nusa Tenggara; this provided her with significant capital in Christian-majority Kupang, and granted her recognition at the grassroots level and in the government.

These types of capital provided a foundation for Sofia's bargaining with political parties, as a result of which she became elected to the Kupang Regency Parliament. Becoming the chairwoman of the Nasdem Party's Kupang branch, she was ultimately re-elected in 2014 and 2019. In this case, we can consider that cultural capital, together with other capitals, can help agents gain positions in multiple fields.

Other civil society actors chose a different route when entering the state through electoral processes. For example, Tomy Yulianto employed a double track approach when penetrating the state, first being elected to parliament before gaining a central position within the executive branch.

In the first track, Tomy Yulianto used his cultural and social capital to become a member of the local parliament, becoming the Deputy Speaker of the Bulukumba Regency Parliament. In the second track, he used his civil society networks and the symbolic capital that he had accumulated as Deputy Speaker to become vice-regent. After crossing over into the state (within the legislative branch), he used his position to reinforce his social capital and gain greater recognition:

Many community activists and media groups used me as a reference, and so people said that I was a media darling. For instance, when disagreements emerged between the local government and parliament, l'd be asked to comment. As I often interacted with the media, and with my civil society allies in Bulukumba, I became more widely known. (Tomy Yulianto, interview, April 20, 2019)

This broad recognition provided Tomy Yulianto with significant capital, and other CSO activists ultimately urged him to run for executive election: "I had never thought of becoming deputy regent and contesting the elections. However, many youths and media actors-who had never known me before-shared the same vision. There thus emerged discourse that I should contest the election" (Tomy Yulianto, interview, April 20, 2019).

Several conclusions may be drawn regarding the use of elections as a direct strategy for boundary crossing. First, actors' habitus, advocacy orientation, and empowerment activities provide a logical foundation for their boundary crossing practices. This foundation is necessary not only because it shapes civil society leaders' actions, but also because it provides a basis for establishing links with political parties and entering the state field. Second, CSO leaders' cultural and social capital, including their networks, provide a basis for their participation in political parties and electoral processes. Such actors do not necessarily limit themselves to parliament; they may also employ a double track, using the legislative branch as a stepping stone for entering the executive branch.

\subsubsection{Indirect Strategy}

CSO leaders have not only relied on direct strategies to enter the state field; indirect strategies have also been used. Such strategies enable CSO leaders to improve their knowledge while expanding their networks with civil society actors and politicians. They are involved in political processes to a certain extent, such as serving as candidates' campaign staff.

Indirect approaches involve a lengthy process through which CSO leaders move from one subfield to another, zig-zagging closer to the state field while remaining within the civil society field. Although they are all motivated to become part of the post-authoritarian state, CSO leaders vary in their use of capital and approaches.

Generally, indirect strategies are used by CSO leaders who cross the boundary to the state while remaining active within civil society. Such strategies may involve movement between subfields, or the expansion of networks between them. Such mobility does not necessarily guarantee that CSO leaders can accumulate more capital; they may also lose existing capital. Mobility is made possible by leaders' knowledge accumulation and networking activities. The experiences of CSO leaders such as Teten Masduki can illustrate this process. Teten Masduki began his CSO career as a human rights activist under the authoritarian New Order government, an experience that enabled him to accumulate significant knowledge regard- 
ing authoritarian regimes and understand Indonesia's future political trajectory. As he stated in an interview with $\mathrm{CNN}$, he chose to migrate from the human rights subfield to the anti-corruption subfield because he recognised that the authoritarian regime would soon collapse. In its wake, it would leave a legacy of corruption. As he stated: "The authoritarian New Order regime was built on violence and corruption. I saw that, even if the regime was replaced, these two problems would remain in the government. That is why I established Indonesia Corruption Watch" (Teten Masduki as cited in Fauzie, 2020).

By becoming an anti-corruption activist, Teten Masduki lost the symbolic capital of public recognition as a human rights activist. At the same time, however, he accumulated new capital: knowledge of corruption and broad media networks (made possible owing to the issue's high profile). He was thus often interviewed by the media, and over time this enabled him to gain public recognition as an anti-corruption activist.

With this recognition, Teten was able to establish networks with politicians and anti-corruption activists. His conversion of symbolic capital to social capital significantly influenced his boundary-crossing activities. He used his capital to become a member of Joko Widodo's campaign staff during the 2014 presidential election, where he was able to link politicians with anti-corruption activists to advance their shared interests. Several activists became part of the new government after Joko Widodo was elected.

An indirect strategy was also employed by Kanti, a CSO leader who migrated from the human rights subfield to the anti-corruption subfield. Drawing on this experience, she became a member of the legal staff at the Ministry of the Environment and Forestry. When she migrated, she lost her social capital (i.e., her networks with marginalised peoples). As she stated:

The Legal Aid Institute (LBH) is a subfield that worked closely with the poor and the marginalised, while Indonesia Corruption Watch (ICW) is an elitist subfield, as it deals with issues that directly affect political elites. Where LBH deals directly with those who are truly powerless, both in terms of their finances and in terms of their bargaining power, ICW deals with cases that are very elitist. (Kanti, interview, May 7, 2019)

Although Kanti lost her social capital, her experiences with anti-corruption activism enabled her to accumulate new knowledge and become broadly known as dealing directly with corruption. In 2018, recognising her capacity as a lawyer, the Ministry of the Environment and Forestry recruited her to its legal staff. According to Kanti, "this institution required someone who could deal with corruption issues" (Kanti, interview, May 7, 2019).

Boundary crossers may also expand their networks with those in power, thereby enabling them to reinforce their social capital and penetrate the state field. Such an approach has been used by the CSO leaders in the
Consortium for Agrarian Reform (KPA, a CSO that promotes agrarian reform). Usep Setiawan, one of KPA's leaders, was made the chairman of the Land Committee at the National Land Office (BPN) in 2006 owing to his close relationship with the Brighten Institute, led by Joyo Winoto. This organisation worked closely with President Susilo Bambang Yudhoyono, and when Joyo Winoto was appointed director of BPN he involved several of his allies.

With the end of Susilo Bambang Yudhoyono's presidency, leaders such as Usep Setiawan used a different strategy to enter the state field, establishing close ties with Joko Widodo's campaign staff. By doing so, they were able to ensure that their political networks were maintained; at the same time, they guaranteed that they could continue to exert political influence. This can be seen by the inclusion of several KPA leaders in Joko Widodo's government through the Presidential Staff Office (KSP).

In their boundary crossing activities, KPA leaders used a unique approach. Even after entering the state field, they remained active in civil society. Indeed, they used their boundary crossing activities to expand their influence in civil society. In other words, this approach has involved 'boundary spanning.'

Based on these cases, it may be concluded that CSO leaders do not enter the state field through a singular channel, but rather a lengthy process. Three important processes are used in the indirect strategy: first, moving to another subfield within the civil society field before entering the state field, through which civil society leaders accumulate more social and cultural capital. Second, moving to another subfield while broadening their political networks by establishing political links by being actively engaged in electoral processes as campaign staff; third, establishing networks with civil society organisations that have political links with the ruler and are actively engaged in political processes.

\section{Political Implications of Boundary Crossing}

The involvement of civil society in policymaking is the main characteristic of post-authoritarian politics, with the implication that such involvement can promote the creation of political linkages and democratic spaces (Lay, 2017a, 2017b). This strategic role in ensuring popular control over public affairs enables CSOs to become political entities with a representational function in a democratic state (Törnquist, 2009).

CSOs have continued to debate the question of CSO actors' involvement in the state. Many civil society actors have doubted their ability to play a representative role in formulating domestic policies and agendas. However, this study has shown that CSO leaders can-to a certain degree-drive sectoral change when they have a position within the state field. Furthermore, they can create political linkages with CSO actors outside the state field. In several cases, these leaders' habitus within the state re- 
mains strongly influenced by the habitus created through their civil society experiences, and this enables them to play a control function in policymaking processes.

Such sectoral changes are inexorably linked with CSO leaders' backgrounds before entering the state field. For example, CSO leaders with a background in agrarian issues tend to focus on agrarian policy. One such group has continued to influence agrarian policy since first gaining influence under President Susilo Bambang Yudhoyono. However, as one activist admitted, their ideas of agrarian reform sometimes lose their spirit in translation (Usep Setiawan, interview, June 27, 2019). Another CSO leader who has promoted sectoral change is Tomy Yulianto, whose background as an environmental activist focused on issues of empowerment and agrarian law has influenced his activities in the legislative and executive branches. He has, for example, passed local bylaws recognising customary societies, promoting corporate social responsibility, and regulating agricultural land. Such an emphasis on sectoral issues, however, has one fundamental shortcoming: Sectoral agendas are built upon a logic of difference, and as such CSO leaders often fail to develop broader political alliances.

Aside from promoting change through public policy, CSO leaders also seek to control policymaking processes. This indicates that their habitus does not change significantly when entering the state field. This can be illustrated through the case of Tomy Yulianto, who was capable of rejecting the annual Accountability Report of the Regional Executive; as he said, "Such an event had never happened in the history of Bulukumba Regency" (Tomy Yulianto, interview, April 20, 2019).

Finally, CSO leaders who enter the state have an important role in developing political linkages with groups or organisations outside the state field. Such linkages are often established as part of sectoral policymaking and advocacy.

\section{A Comparative Sketch of Boundary Crossing: Experiences in Indonesia and Other Countries}

It is important to note that boundary crossing does not happen exclusively in Indonesia, and as such a comparative sketch is necessary to understand the similarities and differences in boundary-crossing strategies around the world. In Brazil, for example, Abers and Tatagiba (2015) found that CSO activists have used the state arena to conduct 'institutional activism.' David Lewis (2008), an important figure in boundary-crossing studies, provided a detailed examination of boundary crossing in three countries: the Philippines, Bangladesh, and the United Kingdom. These countries have fundamental differences. In the Philippines, boundary crossing has occurred as a result of the political transition from authoritarianism to democracy. As such, its boundary-crossing processes have been more political. In Bangladesh, conversely, boundary crossing has been driven primarily by the state's own inability to provide public services and by CSOs' strategic influence (resulting in part from their foreign funding). Consequently, boundary crossing has taken a different direction, with actors moving from the state to civil society. In the UK, boundary crossing has occurred as a result of transformations in domestic institutions and stronger international development programmes. At the domestic level, the state has created collaborative schemes and partnerships with other sectors, particularly CSOs in the social services. To strengthen its role as an international donor, the Department for International Development has created space for CSOs to become involved in the fund management.

Boundary-crossing practices in Indonesia are similar to those in the Philippines, both in their context and in their nature. CSO actors have been driven to enter the state field; similarly, boundary-crossing activities are political, with CSO actors being driven to enter politics by democratisation. However, there are significant ideological differences between the Philippines and Indonesia. In the Philippines, boundary crossing is facilitated by strong ideological links and roots between CSO and political parties. Such a phenomenon is not present in Indonesian CSO activists' boundary-crossing practices.

Boundary-crossing practices in Indonesia also differ significantly from those in Bangladesh. In Indonesia, the state has a strong position. The state becomes a space into which CSO actors eagerly move. Although Indonesian CSO activists receive significant assistance from foreign donors, the State is still irreplaceable. As such, in Indonesia, actors leave CSOs to enter the state, while in Bangladesh they abandon the state to enter civil society. Boundary crossing in Indonesia also differs from the practice in the United Kingdom, as it has not resulted from the rearrangement of social service programmes and because Indonesia is not a donor country (i.e., its CSOs cannot be involved in international agendas). The lack of international dimensions significantly distinguishes Indonesian CSOs from their brethren in the United Kingdom.

\section{Conclusions}

CSO elites may cross boundaries and enter the state field by using 'direct and indirect strategies.' In the former, leaders use elections to gain the access and authority necessary to directly influence policymaking. In the latter, meanwhile, elites make a 'zig-zag' movement before entering the state field. In the direct strategy, actors' habitus, advocacy orientation, and empowerment activities provide a logical foundation for their boundarycrossing practices. This logic is necessary not only because they shape civil society leaders' actions, but also because it provides a basis for establishing links with political parties and entering the state field. Moreover, a direct strategy is also made possible by CSO leaders' cultural and social capital, such as their knowledge and networks. These provide a basis for CSOs' participation in political parties and electoral processes. Finally, in this 
strategy, such actors do not necessarily limit themselves to parliament; they may also employ a double track, using the legislative branch as a stepping stone for entering the executive branch.

When using indirect strategies, CSO leaders do not enter the state field through a singular channel, but rather a lengthy process. These leaders' approaches to entering the state field vary, but inexorably involve processes of capital gain and loss. The indirect strategy may take one of three forms: first, by moving between subfields within civil society before entering the state field; second, by moving to another subfield within civil society and then expanding political networks by actively engaging in political processes such as elections (i.e., by providing loyal support to politicians as campaign staff or volunteers); third, by broadening networks with civil society organisations that have strong political links with the ruler.

Although CSO leaders may use direct and indirect strategies to cross boundaries, election processes remain crucial. We can see that several CSO leaders, even when not engaged as candidates in elections, actively serve as campaign volunteers. These activities provide them with important momentum for creating political contracts with politicians and entering and influencing the state.

Boundary-crossing processes also transform civil society leaders. Direct strategies transform them into politicians or state officials, while indirect processes offer them the ability to expand their influence, becoming not only civil society leaders but also special staff with a strategic role in state institutions. These new roles enable them to influence post-authoritarian political processes, and although they cannot entirely transform political structures, they can still promote some significant changes. Boundary crossers generally promote sectoral policy agendas, based on their backgrounds and experiences. Boundary crossers from the agrarian subfield, for example, continue to promote agrarian reform. At the same time, they establish political linkages and shape public policy.

\section{Acknowledgments}

This article was written as a part of the project "Civil Society Elites in Indonesia and Cambodia" between the Department of Political Science, the Faculty of Social Science, Lund University, Sweden, and the Department of Politics and Government, the Faculty of Social and Political Sciences, Universitas Gadjah Mada, Indonesia. I would like to thank Lund University, Sweden, and Universitas Gadjah Mada, Indonesia, for all of their support. I also would like to thank Anders Uhlin and Håkan Johansson as editors of this thematic issue and three anonymous reviewers for their valuable comments, which helped substantially to improve the article. I also give my gratitude to all participants, individuals, and organizations who provided valuable pieces of information and supported fieldwork. I also would like to ac- knowledge all researchers and research assistants in the Politics and Government Research Centre (PolGov) who were involved in the research process. My gratitude also for Ignasius Jaques Juru for his valuable contribution in the discussion. I would also like to acknowledge Indah Surya Wardhani, Norin M.R Abheseka, and Obed Kresna for their supports.

\section{Conflict of Interests}

The author declares no conflict of interests.

\section{References}

Abers, R. N., \& Tatagiba, L. (2015). Institutional activism: Mobilising for women's health from inside the Brazilian bureaucracy. In F. M. Rossi \& M. von Bulow (Eds.), Social movement dynamics, new perspectives on theory and research from Latin America (pp. 73-101). London: Routledge.

Alagappa, M. (2004). Civil society and political change: An analytical framework. In M. Alagappa (Ed.), Civil society and political change in Asia (pp. 25-57). California, CA: Stanford University Press.

Aspinall, E. (2004). Indonesia: Transformation of civil society and democratic breakthrough. In M. Alagappa (Ed.), Civil society and political change in Asia (pp. 61-96). California, CA: Stanford University Press.

Bourdieu, P. (1986). The form of capital. In J. Richardson (Ed.), Handbook of theory and research for the sociology education (pp. 241-258). New York, NY: Greenwood Press.

Bourdieu, P. (1989). Social space and symbolic power. Sociological Theory, 7(1), 14-25.

Bourdieu, P. (1996). The state nobility: Elite schools in the field of power. Cambridge and Oxford: Polity Press and Blackwell Publisher.

Bourdieu, P., \& Wacquant, L. (1992). An invitation to reflexive sociology. Cambridge: Polity Press.

Brinkerhoff, D. W., \& Brinkerhoff, J. M. (2011). Publicprivate partnerships: perspective on purposes, publicness, and good governance. Public Administration and Development, 31(1), 2-14.

Chandhoke, N. (2001). The 'civil' and the 'political' in civil society. Democratisation, 8(2), 1-24.

Duile, T., \& J., Bens (2017). Indonesia and the 'conflictual consensus': A discursive perspective on Indonesian democracy. Critical Asian Studies, 49(2), 139-162.

Eldridge, P. (1996). Development, democracy, and nongovernment organization in Indonesia. Asian Journal of Political Science, 4(1), 17-35.

Fauzie, Y. Y. (2020, January 8). Teten Masduki, anak juragan tepung jadi pembantu Jokowi [Teten Masduki, the son of flour trader becomes Jokowi's assistant]. CNN Indonesia. Retrieved from https://www. cnnindonesia.com/ekonomi/20200107170607-98463208/teten-masduki-anak-juragan-tepung-jadipembantu-jokowi/2 
Hoffman-Lange, U. (2017). Theory-based typologies of political elites. In H. Best \& J. Higley (Eds.), The Palgrave handbook of political elites (pp. 53-68). New York, NY: Palgrave Macmillan.

Ichwanuddin, W. (Ed.). (2010). Transformasi politik aktivis CSO: Refleksi pengalaman caleg aktivis dalam pemilu 2009 [The political transformation of activist CSO: Reflections on the activists' experiences who run for the legislative candidates in the 2009 election]. Jakarta: LIPI and Yayasan Tifa.

Lay, C. (2017a). Political linkages between CSOs and parliament in Indonesia: A case study of political linkages in the Aceh governance law. Asian Journal of Political Science, 25(1), 1-21.

Lay, C. (2017b). The emergence of new democratic space: CSOs and parliament in post-Suharto Indonesia. Power, Conflict and Democracy Journal, 5(1). https://doi.org/10.22146/pcd.26286

Lewis, D. (2008). Crossing the boundaries between 'third sector' and state: Life-work histories from the Philippines, Bangladesh and the UK. Third World Quarterly Journal, 29(1), 125-141.

Manor, J. (2013). Post-clientelist initiatives. In K. Stokke \& O. Törnquist (Eds.), Democratization in the Global South. New York, NY: Palgrave.

Maton, K. (2008). Habitus. In M. Grenfell (Ed.), Pierre Bourdieu key concepts (2nd ed., pp. 48-64). New York, NY: Routledge.

Mietzner, M. (2013). Fighting the hellhounds: Prodemocracy activists and party politics in post-Suharto Indonesia. Journal of Contemporary Asia, 43(1), 28-50.

Moore, G., Sobieraj, S., Whitt, J. A., Mayorova, O., \& Beaulieu, D. (2002). Elite interlock in three U.S. sectors: Nonprofit, corporate, and government. Social Science Quarterly, 83(3), 726-744.

Mundayat, A. A., Narendra, P., \& Irawanto, B. (2009). State and civil society relationships in Indonesia: A society-oriented reading in search for democratic space. Power, Conflict, and Democracy Journal, 1(1/2). https://doi.org/10.22146/pcd.25678

Nielsen, K. B. (2012). 'An activist can't become a politician': Social activism, leadership and the (un)making of political career in an Indian state. Contemporary South Asia, 20(4), 435-453.

Noor, F. (2010). Pasang-surut hubungan antara civil soci- ety dan negara era Orde Baru [The dynamic relationship between civil society and the state in the New Order Era]. In W. Ichwanudin (ed.). Transformasi politik aktivis CSO: Refleksi pengalaman caleg aktivis dalam pemilu 2009 [The political transformation of activist CSO: Reflections on the activists' experiences who run for the legislative candidates in the 2009 election]. Jakarta: LIPI and Yayasan Tifa.

Perdana, A. (2015). The politics of civil society organisations (CSOs) in post-reformation 1998. Jurnal Sosiologi Masyarakat, 20(1), 23-42.

Priyono, A., Prasetyo, S. A., \& Törnquist, O. (2003). Gerakan demokrasi di Indonesia pasca Soeharto [Democratic movement in Indonesia's post-Suharto]. Jakarta: Demos.

Rosenblum, N. L., \& Lesch, C. H. L. (2011). Civil society and government. In M. Edwards (Ed.), The Oxford handbook of civil society. Oxford: Oxford University Press.

Ryker, J. (1995). Contending perspectives for Interpreting government-NGO relations in South and Southeast Asia: Constraint, challenges and the search for common ground in rural development. In N. Heyzer, J. V. Ryker, \& A. B. Quizon (Eds.), Government-NGO relations in Asia. Kuala Lumpur:APDC.

Samadhi, W. P., \& Törnquist, O. (2016). In A. Savirani \& O. Törnquist (Eds.), Reclaiming the state: Overcoming problems of democracy in post-Soeharto Indonesia. Yogyakarta: PolGov.

Savirani, A., \& Törnquist, O. (Eds). (2016). Reclaiming the state: Overcoming problems of democracy in postSoeharto Indonesia. Yogyakarta: Polgov.

Stokke, K., \& Törnquist, O. (2013). Democratization in the Global South: The importance of transformative politics. New York, NY: Palgrave.

Swartz, D. (1997). Culture and power: The sociology of Pierre Bourdieu. Chicago: University Chicago Press.

Törnquist, O. (2009). The problem is representation! Towards an analytical framework. In K. Stokke, N. Webstern, \& O. Törnquist (Eds.), Rethinking popular representation. New York, NY: Palgrave.

Uhlin, A. (1997). Oposisi Berserak: Arus Deras Demokratisasi Gelombang ketiga Di Indonesia [Indonesia and the "Third Wave of Democratization": The Indonesia pro-democracy movement in a Changing World]. Bandung: Mizan Pustaka.

\section{About the Author}

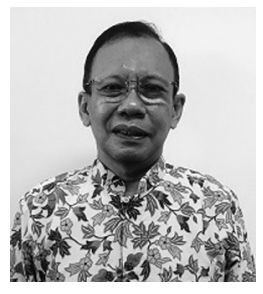

Haryanto is a Professor of Political Science at the Department of Politics and Government, Faculty of Social and Political Science, Universitas Gadjah Mada, Indonesia. His research interests include local political elite, democracy and conflict studies, and local government studies. Haryanto is the author of several books and journal articles, including "Sistem Politik: Suatu Pengantar" [Political System: An Introduction] (1982), "Kekuasaan Elite: Suatu Bahasan Pengantar" [The Power of Elite: An Introductory Elaboration] (2005), "Territory, Class, and Kinship: A Case Study of an Indonesian Regional Election" (co-authored and published in Asian Politics and Policy Journal, 2019), and "Power in the Tradition of Kain Timur Exchange: A Study of Using Tradition to Get Support in Local Election in South Sorong 2010" (published in Power, Conflict, and Democracy Journal, 2017). 